Nobilities in the Portuguese America:

\title{
Nobrezas na América portuguesa: notas sobre as estratégias de enobrecimento na capitania de Minas Gerais
}

notes on the strategy of ennoblement (XVIIIth Century Minas Gerais)

\author{
Roberta Giannubilo Stumpf \\ Doutora em História Social pela \\ Universidade de Brasilia (IH/UNB \\ - Brasília/Brasil) e pós-doutoranda \\ do Centro de História do Além-Mar \\ da Universidade Nova de Lisboa \\ (CHAM/UNL - Lisboa/Portugal) \\ e-mail: robertastumpf@gmail.com
}

\begin{abstract}
Resumo
Neste artigo, a discussão sobre as possibilidades de enobrecimento a que podiam aspirar os habitantes da América portuguesa ao longo do Setecentos é o ponto de partida para se reavaliar os conceitos utilizados pela historiografia sobre as elites sociais luso-americanas. A análise das nobrezas da capitania das Minas Gerais, em especial, das trajetórias ascensionais dos cavaleiros das ordens militares ali residentes, constitui a base empírica para a percepção da heterogeneidade do referido grupo e da superioridade, em seu interior, que adquiriam aqueles que conquistavam o status de nobre porque sua notoriedade local fora reconhecida e sancionada pelo centro político da monarquia lusa.
\end{abstract}

\begin{abstract}
The debate over the chances of ennoblement opened to the inhabitants of Portuguese America in the eighteenth century will be the starting point for a revaluation of the concepts about the Luzo-American elites employed by the historiography. The analysis of the nobilities in the captaincy of Minas Gerais centred in the knights of the military orders living in that territory constitutes the empirical base to grasp their heterogeneity and the preeminent status acquired by those who had their local notoriety sanctioned by a superior distinction given by the Portuguese monarchy.
\end{abstract}

Palavras-chave

sociedade, América portuguesa/Brasil, Antigo Regime, Colônia

Keywords

society, Portuguese America/Brazil, Ancient Regime, Colony 
1

JANCSÓ, István ; PIMENTA, João Paulo Garrido. Peças de um mosaico (apontamentos para o estudo da emergência da identidade nacional brasileira. In: MOTA, Carlos Guilherme (org.). Viagem incompleta. A experiência brasileira (1500-2000). 2ed. São Paulo: SENAC, Formação: histórias, 2000. p.127-175. STUMPF, Roberta. Filhos das Minas, americanos e portugueses. Identidades coletivas na capitania das Minas Gerais (1763-1792). São Paulo: Fapesp/Hucitec, 2010.

2

JANCSÓ, István. Brasil e brasileiros - Notas sobre a modelagem de significados políticos na crise do Antigo Regime português na América. Estudo Avançados, n.22 (62), p.259-260, 2008.

3

ANTONIL, André João. Cultura e opulência do Brasil por suas drogas e minas. São Paulo: EDUSP, 2007. p.79
A renovação historiográfica sobre as formas de integração das diferentes partes da América na monarquia portuguesa trouxe novas perspectivas analíticas acerca das elites coloniais, em particular no que se refere às suas esferas de atuação e às estratégias percorridas para a consolidação do seu prestígio local. 0 pressuposto de que as relações entre o centro político e os domínios ultramarinos pautaram-se também pela negociação tem contribuido para que alternativas de engrandecimento social específicas do contexto americano passassem a dividir a atenção dos historiadores com aquelas que percorriam as vias oficiais. Não surpreende, portanto, a ênfase dada ao impacto gerado pelo sistema de doação de mercês régias na consolidação das hierarquias sociais na América e a sua importância na formação de uma nobreza reconhecida jurídica e oficialmente, tema que nos interessa em particular. Não se trata de analisar esta conquista como um imenso Portugal, mas de considerar que seus habitantes também acolheram os critérios hierárquicos trazidos pelos colonizadores. Se os súditos aqui residentes podiam se reconhecer como americanos eram também portugueses e expressavam seus sentimentos de adesão à monarquia portuguesa ${ }^{1}$, em diversos níveis.

\section{Estratégias de nobilitação na América portuguesa}

Antes de tudo, é preciso salientar que a existência em terras americanas de uma nobreza titulada pela monarquia não pressupõe que a sociedade colonial tenha se estruturado como uma réplica do modelo hierárquico reinol. Se é possivel notar aspectos convergentes, é igualmente relevante atentarmos para aquilo que singularizava a vida social na colônia, a qual, nas palavras de István Jancsó, apresentava estruturas "simultaneamente replicantes e desviantes dos paradigmas europeus"2. Entender a coexistência destes diferentes critérios de ordenação social suscita grandes dificuldades aos historiadores que centram suas pesquisas na compreensão da sociedade americana, razão pela qual também aqui este tópico ocupa, em larga medida, as nossas reflexões.

A primeira e mais importante questão a ser respondida, e que permeia todas as demais, é saber como as categorias sociais do modelo estamental podem ser aplicadas para se compreender uma realidade que apresentava formas de diferenciação social menos expressivas no Reino. Não há como negar que na América o estabelecimento da escravidão e a presença maciça do elemento africano determinaram que as polaridades livres/escravos e brancos/homens de cor se tornassem uma das principais referências ao escalonamento dos indivíduos; oposições que não tinham a mesma relevância em Portugal, onde os escravos africanos eram em número inferior e utilizados quase que exclusivamente nos espaços domésticos e em algumas explorações agrícolas. Somados a isso, a posse de cativos e terras pelos homens livres, na sua maioria de descendência reinol, conferia aos proprietários autoridade política e social, tal como escreve Antonil em 1711, para quem "bem se pode estimar no Brasil o ser senhor de engenho quanto proporcionalmente se estimam os títulos entre os fidalgos do Reino"s.

0 testemunho do jesuíta italiano, tantas vezes citado em trabaIhos historiográficos, certamente contribui para embasar a tese de que a América era "um lugar adequado para a efetivação do sonho do enobrecimento", principalmente porque o escravismo teria ratificado "uma espé- 
ROMEIRO, Adriana \&t BOTELHO, Ângela Vianna. Dicionário Histórico das Minas Gerais. Belo Horizonte: Autêntica, 2003. Verbete "sociedade", p.287.

5

Acresce que, ser senhor de engenho e possuir escravaria também podia pressupor uma outra dimensão, a saber, a posse de um dispositivo de coerção (inclusive paramilitar) muito importante em certos contextos. FRAGOSO, João Luiz. Potentados coloniais e circuitos imperiais: notas sobre uma nobreza da terra, supracapitanias, no setecentos. In: MONTEIRO, Nuno Gonçalo; CARDIM, Pedro; CUNHA, Mafalda S. da (org). Optima Pars. Elites ibero-americanas do Antigo Regime. Lisboa: ICS, Imprensa de Ciências Sociais, 2005. p. 137.

6

Tal como afirmava Diogo Camacho de Aboim, no século XVII: "com as virtudes se adquirem as riquezas, mas com as riquezas não se compram as virtudes; (....) donde bem pode ser rico o que é virtuoso, mas não é conseqüência que seja virtuoso, o que é rico". ABOIM, Diogo Guerreiro Camacho de. Escola Moral, política, cristã e jurídica. Lisboa: Oficina de Bernardo Antonio de Oliveira, 1754. p.54. (3ªedição)

\section{7}

GOUVÊA, Maria de Fátima. Os homens da governança do Rio de Janeiro em fins do século XVIII e início do XIX. In: VIEIRA, Alberto (coord). 0 município no mundo português. Funchal: CEHA/ Secretaria Regional de Turismo e Cultura, 1998. p.549.

8

BICALHO, Maria Fernanda. As câmaras ultramarinas e o governo do Império. In: FRAGOSO, João; GOUVÊA, Maria de Fátima Silva; BICALHO, Maria Fernanda (org). O Antigo Regime nos Trópicos. A dinâmica imperial portuguesa. (séculos XVI-XVIII). Rio de Janeiro: Civilização Brasileira, 2001. p.200. cie de popularização da fidalguia"4 ${ }^{4}$. No entanto, se Antonil acentuava a importância dos aspectos locais ao estabelecimento das hierarquias sociais, parece exagero concluir que as nobrezas coloniais se distanciavam de todo da imagem atribuída ao grupo nobiliárquico segundo os pressupostos estamentais.

Quando aprofundamos a investigação sobre as elites coloniais, vemos que o autor provavelmente referia-se a uma espécie de nobreza, caracteristica das zonas açucareiras, que não era certamente a única $e_{1}$ tampouco, a mais importante. No que se reporta à dimensão mais evidente $^{5}$, ou seja, a riqueza, esta sem dúvida era fonte de reputação social e, muitas vezes, representou o primeiro degrau nas carreiras ascensionais, já que o cabedal econômico poderia ser convertido em cabedal simbólico. Mas também na América portuguesa existiam outras formas de nobilitação prestigiadas que, por não estarem vinculadas estritamente à riqueza dos indivíduos, harmonizavam-se aos paradigmas hierárquicos próprios do modelo europeu. Ao menos àqueles tidos como ideais, nos quais o mérito do dinheiro não equivalia em importância, nas trajetórias ascendentes, à honra herdada ou adquirida. ${ }^{6}$

A recente historiografia brasileira tem atentado para isso e, não obstante as pesquisas versem sobre territórios específicos que compunham a América, elas permitem concluir que em todos os cantos desta conquista estratégias de afirmação social se repetiam, embora ganhassem relevâncias distintas a depender das realidades locais. A leitura destas fontes deixa evidente que os homens abastados não se refugiavam em suas propriedades e reinavam ali soberanos como se seu prestígio dependesse unicamente do volume de seu cabedal. Tencionavam, preferencialmente, engrandecer seu poder adentrando os círculos sociais restritos aos "principais da região", como as câmaras, as Santas Casas de Misericórdias ${ }^{7}$ ou as mais estimadas irmandades. Nestas últimas reforçavam e consolidavam suas reputações, não só porque estabeleciam importantes redes de poder, mas também porque nestas instituições caritativas podiam ostentar a virtude de serem bons cristãos, atributo condizente com o status de nobre com o qual desejavam verem-se reconhecidos.

Mais importante ainda às trajetórias ascensionais era perseguir uma carreira "pública", não só porque os serviços obrados em tais postos poderiam render uma remuneração régia, mas também porque localmente os servidores eram reconhecidos como homens que portavam notoriedade e estima social já que, em teoria, só eram providos aqueles que possuiam qualidades que os destacavam da massa de homens comuns. Assim, muitos proprietários de terras e escravos, visando aumentar a sua reputação, deixavam seus bens para serem administrados por terceiros para se dedicarem aos ofícios administrativos ou militares.

Entretanto, nem sempre é possível saber com exatidão quais eram estes atributos distintivos que tornavam um súdito apto para representar a autoridade real, já que as leis e normas que regularizavam estas nomeações não seguiam critérios estanques. 0 acesso aos postos camarários, por exemplo, dependia muito mais dos parâmetros locais e da boa inserção nas redes de poder estabelecidas em cada uma das partes da América, do que da anuência do poder real. Há muito que estudar sobre a eventual intervenção que o monarca passou a exercer nas câmaras com a criação do cargo de juiz de fora, oficial nomeado pela Coroa a partir da segunda metade do século XVII. ${ }^{8}$ De qualquer forma, sua atuação no Ultramar 
Idem. As representações da câmara no Rio de Janeiro ao monarca e as demonstrações de lealdade dos súditos coloniais. Séculos XVII e XVIII. In: VIEIRA, Alberto (coord). 0 município no mundo português..., Op.cit, p.525.

10

MONTEIRO, Nuno Gonçalo. Notas sobre a nobreza, fidalguia e titulares nos finais do Antigo Regime. Ler história, Lisboa, n.10, p.24, 1987. Idem. Elites locais e mobilidade social em Portugal nos finais do Antigo Regime. Análise Social, Lisboa, Volume XXII, n¹41, p.339, 1997.

11

VIDIGAL, Luis. No microcosmo social português: uma aproximação comparativa à anatomia das oligarquias camarárias no fim do Antigo Regime político (1750-1830). In: VIEIRA, Alberto (coord). 0 município no mundo português..., 0p.cit, p.139.

12

PEREIRA, João Manuel Rodrigues. Elites coloniais e liberalismo. Torres Vedras 1792-1878. Torres Vedras: Linhas do Tempo, Edição do Município de Torres Vedras, Cultura, 2000. p.41-42.

Colleção chronológica da legislação portuguesa, ano de 1670, p.592. Disponivel em http:// www. iuslusitania.fcsh.unl.pt. Acesso em 20 de janeiro de 2009.

14

Nas câmaras portuguesas, do reino ou das conquistas, não havia postos vitalícios ou hereditários como ocorria na Espanha, o que não impediu que o poder se mantivesse "nas mesmas familias, e sempre nelas. Menos um poder pessoal, mas um poder de grupo". MAGALHÃES, Joaquim Romero. Reflexões sobre a estrutura municipal portuguesa e a sociedade colonial brasileira. Revista de História econômica e social. n.16, p.21, jul-dez de 1985 .

15

MELLO, Evaldo Cabral de. O nome e o sangue. Uma fraude genealógica no Pernambuco colonial. São Paulo: Companhia das Letras, 1989. parece ter sido bastante limitada, por abranger um número reduzido de vilas, tal como ocorreu em Minas Gerais, onde apenas a câmara da Cidade de Mariana era presidida por tal autoridade. Na verdade, podemos entender que a criação deste posto aponta para as dificuldades encontradas pelo centro político em regularizar uniformemente 0 acesso a estas instituições administrativas. Mesmo que se tenha tentado aplicar leis válidas em todas as possessões portuguesas, estas, a rigor, não eram precisas quanto à qualidade dos homens que nelas poderiam ingressar: As normas jurídicas determinavam apenas que a lista de eleitores e dos elegiveis às câmaras municipais fossem compostas por "pessoas principais da terra" (1570), dos "melhores dos lugares" (Ordenações, 1603), os mais nobres da "governança da terra"9 , dos "melhores da terra" (1618). Mas quais eram os critérios que faziam de um súdito principal, melhor ou com maior grandeza senão os atributos qualificadores vigentes em cada localidade, tal como a legislação nos permite entender?

É por isso que, tanto no Reino como nas conquistas, a composição das câmaras variou substancialmente e a qualidade dos oficiais camarários em cada localidade determinou o prestígio que cada uma dessas instituições podia lograr. Em Portugal, os fidalgos fugiam dos concelhos de menor importância abrindo espaço para que nobres de menor reputação se afirmassem socialmente. ${ }^{10}$ Mesmo assim, ocupar um cargo camarário, em especial os de juiz ordinário, procurador e vereador, sempre foi reconhecido como uma fonte de notoriedade ${ }^{11}$ porque algumas câmaras reinóis eram compostas por aristocratas, sendo os membros recrutados, na sua maioria, entre a "nobreza hereditária ou com distinções nobiliárquicas, definido pela hereditariedade do estatuto ou dos cargos"12.

Nas terras americanas, ser um oficial camarário era, impreterivelmente, uma das vias de afirmação social mais prestigiadas porque representava, para a maioria, o topo da carreira política a que poderiam almejar. Fazer parte de seus quadros significava, também, ter acesso a um importante canal de negociação com o Reino no qual podiam ver os interesses locais atendidos. É por esta razão que os postos nas câmaras foram objeto de disputas entre os principais homens das terras, e nestas viram-se favorecidos, com a introdução do alvará de $1670^{13}$, os descendentes das famílias que já tinham tradição em servi-las, que passaram assim a monopolizá-los. A pouca rotatividade dos cargos contribuiu para a oligarquização das câmaras ${ }^{14}$, embora isso não signifique que elas tenham se tornado um reduto exclusivo da nobreza, no sentido jurídico dado ao termo. Como vimos, as leis exigiam apenas que os elegiveis tivessem proeminência social, sem qualquer referência ao fato de serem ou não oficialmente nobres, ou seja, reconhecidos como tais pela monarquia.

Voltamos então, ao ponto inicial. Se a notoriedade local era condição sine qua non para conquistar em todas as terras portuguesas o privilégio de ser um representante da Coroa, os atributos que a definiam variavam, não obstante as semelhanças fossem mais visiveis do que as diferenças. $\mathrm{Na}$ capitania de Pernambuco, por exemplo, a reputação estava fortemente condicionada pelos vínculos familiares naturais ou adquiridos. ${ }^{15}$ Os descendentes dos súditos que lutaram na guerra da Restauração, ou aqueles que mantinham um relacionamento próximo com os membros de tais linhagens, mereciam deferência pública. Com o decorrer do tempo, ao menos até a Guerra dos Mascates, a autoridade destas famílias foi sendo reforçada, pois a lembrança dos feitos heróicos fazia com que os nomes ficassem regis- 
16

BICALHO, Maria Fernanda. As representações da câmara no Rio de Janeiro..., Op.Cit., p.536. FRAGOSO, João. A nobreza vive em bandos: a economia política das melhores familias da terra do Rio de Janeiro, século XVII. Algumas notas de pesquisa. Topoi-Revista do Departamento de História da UFF, Niterói, v.8, n.15, p.13.

17

ALMEIDA, Carla. Uma nobreza da terra com projeto imperial: Maximiliano de Oliveira Leite e seus aparentados. In: FRAGOSO, João; ALMEIDA, Carla; JUCÁ, Antonio Carlos (org). Conquistadores e Negociantes. Histórias de elites no Antigo Regime nos trópicos. América lusa, séculos XVI a XVIII. Rio de Janeiro: Civilização brasileira, 2007. p.121-193.

18

MESGRAVIS, Laima. Os aspectos estamentais da estrutura social do Brasil Colônia. Estudos econômicos, São Paulo, USP/IPE, n¹3, p.803, 1983.

19

Também na América espanhola, "a antiguidade na terra" justificava a crença dos conquistadores e seus descendentes de terem maior direito a qualquer mercê por serviços próprios ou de seus antepassados, ainda não recompensados. CĖSPEDES DEL CASTILLO, Guillermo. El criollismo. In: TUÑON DE LARA, Manuel. Historia de España. Tomo VI (América Hispânica 1492-1898). Madrid: Editorial Labor, S.A, 1988. p.285

20

Sobre a intensidade da emigração portuguesa à América ver LIVI-BACCI, Massimo. 500 anos de demografia brasileira: uma resenha. Revista brasileira de estudos de população, v.19, n.1, p.147, jan/jun 2002.

21

Sobre a predominância entre a nobreza colonial da "nobreza de serviços". Ver: SILVA, Maria Beatriz Nizza. Ser Nobre na Colônia. São Paulo: Editora UNESP, 2005. p.10.

22

FRAGOSO, João; GOUVÊA, Maria de Fátima Silva; BICALHO, Maria Fernanda. Uma leitura do Brasil Colônia. Bases da materialidade e da governabilidade no Império. Penélope, Lisboa, n.23, p.67-88, 2000. trados na memória coletiva como exemplos de bravura, sacrifício e honra demonstrados em episódios que estavam associados à origem daquela comunidade. Em outras capitanias a proximidade sanguínea ou relacional com os primeiros colonizadores era também uma forma de adquirir estima social ${ }^{16}$, mas nas Minas, por exemplo, a colonização tardia e a expulsão de grande parte dos primeiros exploradores, vale dizer, os paulistas, fizeram com que o ideário da conquista e a antiguidade das famílias estivessem menos presentes no reconhecimento do prestígio alheio. Há exceções, evidentemente, como demonstra o estudo de Carla Almeida sobre as famílias Dias Paes e Hortas, cujos patriarcas conquistaram fidalguia e estabeleceram nas Minas linhagens de reconhecida importância, que irão se perpetuar por todo o século XVIII. ${ }^{17}$ Mas são casos isolados, que não nos autorizam afirmar que nesta capitania eram muitos a se vangloriar de serem descendentes dos primeiros conquistadores, pelo que a memória histórica dos seus primórdios raramente é mencionada como atributo a conferir dignidade aos homens, ao menos nos documentos por nós consultados.

De qualquer forma, em todas as capitanias americanas os homens reconhecidos como pertencentes aos grupos dominantes nem sempre o eram em função de seu sangue. ${ }^{18} \mathrm{Na}$ verdade, estes estavam em minoria, o que propiciou que a "antiguidade na terra" se tornasse um argumento eficaz para reivindicar maior direito aos cargos de mando ou à aquisição de outros privilégios. ${ }^{19}$ Mesmo assim, as elites coloniais foram constantemente se renovando pelo ingresso de recém-chegados do Reino ${ }^{20}$ que, juntamente com outros vassalos já estabelecidos, puderam conquistar notoriedade por mérito exclusivamente pessoal e não familiar.

Tal como já afirmamos, esta autoridade social na maior parte das vezes culminava com as mercês conquistadas mediante os serviços prestados em prol da monarquia, os quais normalmente eram desempenhados por quem já era um representante régio em nível local. Neste sentido, ocupar postos superiores na estrutura administrativa (da Fazenda ou da Justiça), eclesiástica e militar, principalmente nas ordenanças, tornouse uma estratégia ascensional fortemente perseguida ${ }^{21}$, principalmente porque proporcionava um ciclo de engrandecimento contínuo. Prestigiados pelos postos que ocupavam, tais súditos prestavam serviços à monarquia pelos quais podiam conquistar honrarias que elevavam sua importância, podendo, assim, serem providos em cargos ainda mais cobiçados nos quais seus méritos ganhavam maior destaque, como já foi mostrado por muitos estudos, principalmente dos integrantes do que podemos chamar a "Escola do Rio de Janeiro"22.

Importa notar que todas essas vias ascensionais acima referidas não se excluiam, ou seja, não era preciso escolher apenas uma delas, sendo comum aos súditos americanos apostarem em diferentes frentes, diversificando seus perfis e círculos de convivência. Assim, podiam ser proprietários, ter uma patente militar, servir temporariamente nos cargos da vereança, aproximarem-se ou pertencerem às famílias importantes e, nas procissões festivas, ostentar no peito uma insígnia do hábito de Cristo.

Mas independentemente das estratégias escolhidas na conquista de autoridade social, esta devia ser necessariamente exteriorizada mediante a observância de regras de condutas precisas. Em uma sociedade ancorada nas aparências era exigido que os homens reputados vivessem "à lei da nobreza", como se dizia à época, com dignidade, luxo, respeitando os preceitos morais, as virtudes nobres e as cristãs. A reprodução do ethos 
23

Segundo a definição de Oliveira Marques, eram "os mais ricos, os mais notáveis, os mais respeitosos chefes de família, as pessoas honradas por excelência dentro de cada território". Apud MENGRAVIS, Laima. Os aspectos estamentais..., Op.cit., p.800.

\section{4}

FRAGOSO, João Luiz. Potentados coloniais e circuitos imperiais: notas sobre uma nobreza da terra, supracapitanias, no setecentos. In: In: MONTEIRO, Nuno Gonçalo; CARDIM, Pedro; CUNHA, Mafalda S. da (org). Optima Pars..., Op.Cit " p.137. Evidentemente, a simples posse de escravos não "nobilitava", sendo preciso que o proprietário apresentasse outras qualidades que permitissem que fosse reconhecido como um súdito localmente importante. É preciso lembrar que também os libertos, e até mesmo escravos, possuiam cativos. De qualquer forma, tal evidência não invalida nossa afirmativa de que a posse de cativos era um símbolo de distinção ajustado aos parâmetros tradicionais.

25

FERNANDES, Florestan. Circuito Fechado: quatro ensaios sobre o "poder institucional". São Paulo: Hucitec, 1976. p.32-33.

BICALHO, Maria Fernanda. Conquista, mercês e poder local: a nobreza da terra na América portuguesa e a cultura política do Antigo Regime. Almanack brasiliense, n.2, p.24, nota 11, novembro de 2005 aristocrático determinava, também, que se apresentassem publicamente com suas montarias, resquícios do tempo medieval, ou ainda rodeados de escravos, não só porque estes simbolizavam a abastança, mas sobretudo porque evidenciavam a condição dos proprietários como homens livres da mácula da mecânica que, de acordo com o modelo social corporativista, era exigência prévia ao ingresso no grupo dos nobres, já que os oficiais mecânicos constituiam-se a "antítese" do mesmo. 0 senhor de escravos enriquecia-se com o sobretrabalho de seus cativos, reforçava seu poder de mando na sociedade, adquiria a qualidade necessária para ser reconhecido como homem-bom ${ }^{23}$ e servir à república. Suas qualidades enquadravamse, portanto, nas exigências de pertencimento ao topo de uma hierarquia estamental que "consistia no chão da sociedade" colonial. ${ }^{24}$

\section{A aplicação das categorias sociais européias à compreensão das nobrezas coloniais}

Tal como acima pudemos mencionar, a historiografia sobre as sociedades coloniais tem alertado para a diversidade das formas de nobilitação existentes no Ultramar, esforçando-se, com sucesso, em demonstrar que a notoriedade dos indivíduos era atribuida tanto por valores e costumes ibéricos como por aqueles definidos localmente. No entanto, se podemos notar a fundamental contribuição das pesquisas historiográficas mais recentes na compreensão das elites coloniais e das estratégias de ascensão social, estas ainda se deparam com a dificuldade anunciada por Florestan Fernandes, na década de 70, quanto à utilização dos vocábulos para tratar de uma realidade que era, concomitantemente, singular e comum, desviante e replicante. ${ }^{25}$

É verdade que tal dificuldade, em larga medida, justifica o emprego recorrente do termo "nobreza da terra" para se referir ao grupo dominante uma vez que este permite evidenciar um pressuposto cada vez mais compartilhado pela comunidade acadêmica: o de que a nobreza era uma categoria social aplicável também à sociedade americana, não obstante esta apresentasse singularidades e variações locais. Trata-se de um conceito, apropriado e disseminado pela historiografia brasileira, que Evaldo Cabral de Mello mostrou ser pertinente para a compreensão do grupo que na capitania de Pernambuco via-se como superior aos demais e que se autodenominou como "nobres da terra" para evidenciar tal superioridade. Os demais autores, no entanto, não explicitam a genealogia do vocábulo, e nem sempre mostram por meio da documentação quando ou por que era utilizado, mas se fazem uso do mesmo é por notarem que aquelas qualidades atribuídas à nobreza da terra pernambucana também aparecem com força distintiva nas demais capitanias que investigam. Fernanda Bicalho, em artigo de 2005, justifica o emprego do vocábulo enfatizando que mais importante do que saber "se o termo encontra-se ou não na documentação" é discutir "a construção e a legitimidade de utilização do conceito a partir de certos atributos das elites coloniais de diferentes capitanias" 26 . No entanto, se o fato de não encontrarmos este vocábulo na documentação por nós analisada não se configura uma questão de maior relevância, julgamos que a pertinência da sua aplicabilidade deve ser matéria de reflexão, principalmente porque sua utilização apresenta um problema conceitual que merece ser aprofundado.

Se o emprego do conceito "nobreza da terra" permite, por um lado, enfatizar que a nobreza colonial era uma categoria definida por critérios sociais emanados do reino, apropriados e reelaborados localmente, por 
Tese já antes referida por Monteiro em sua análise sobre a "oligarquia municipal". MONTEIRO, Nuno Gonçalo. Elites locais e mobilidade social em Portugal..., Op.cit, p.339. RODRIGUES, José Damião. As elites locais nos Açores em finais do Antigo Regime. Disponivel em: http:// www.ics.ul.pt/agenda/seminarioshistoria/pdf/ josedamiaorodrigues.pdf. Acesso em 20 de setembro de 2006.

28

MONTEIRO, Nuno Gonçalo. Um Império de destinos cruzados. Entrevista concedida à Revista de História da Biblioteca Nacional, ano 1, no. 11, agosto de 2006, p.52.

29

BICALHO, Maria Fernanda. Conquista, mercês e poder local...., Op.Cit, p.30.

30

D'ALCOCHETE, Nuno Daupiás. Principalidade. Coleção Registros da História, n.2, Centro de estudos de genealogia, heráldica e história da família da Universidade do Porto.

31

Conforme F. Francisco Barreiros. "livro da verdadeira nobreza" (século XVII), s/d NA/ T, Coleção de S. Vicente, cx.7. Apud. SOARES, Sérgio da Cunha. Nobreza e arquétipo fidalgo - A propósito de um Livro de Matrículas de Filhamentos (1641-1724). Revista de História das Idéias, Lisboa, v.19, p.403-406, 1997. outro, ele tende a atribuir uma homogeneidade a este grupo como se todos os homens que pertencessem a ele fossem reconhecidos como portadores de uma reputação social similar. 0 que estamos procurando mostrar é que se no interior da nobreza americana, à semelhança do que ocorria no Reino e nas Ilhas Atlânticas, existiam vários níveis de honra e poder que conferiam aos indivíduos status de desigual grandeza, como aliás já foi notado por Rodrigues sobre as elites açorianas, a utilização do conceito acima referido dificulta o reconhecimento da heterogeneidade deste grupo. ${ }^{27} \mathrm{E}$ preciso prestar atenção para o fato de que as alternativas de ascensão social percorridas nem sempre eram as mesmas e que a reputação que atribuíam variava em importância. A questão que se coloca, então, é saber qual delas conferia maior prestígio.

Ainda que a historiografia não tenha colocado esta questão nestes termos, ao dar maior relevância à reputação advinda do exercício do mando nas câmaras ultramarinas de alguma forma acaba por se posicionar. Muitas vezes, o termo "nobreza da terra" é empregado como sinônimo de "nobreza da governança da terra", ou seja, para se referir aos homens ligados ao poder político do município; associação absolutamente pertinente já que é assim que a "nobreza da terra", enquanto categoria jurídica, aparece na legislação portuguesa: são os homens bons que podiam compor a lista dos eleitores e elegiveis às câmaras. ${ }^{28}$ Mas, nem sempre, esse termo é empregado de forma precisa, pois aparece para nomear todas as elites sociais ${ }^{29}$, e não apenas a política, pouco se diferenciando, portanto, da noção de principalidade, vigente nos séculos XVI ao XVIII. Esta última compreendia um número bem vasto de indivíduos, todo aquele que era "influente, prestigioso de um lugar ou vila (que) podia ser nobre ou plebeu"30.

Veja-se assim que a historiografia ao utilizar conceitos generalizantes para denominar os grupos que possuiam hegemonia social, elites ou nobrezas da terra, acaba por minimizar a hierarquia entre as nobrezas $e_{\text {, }}$ paradoxalmente, por desconsiderar o que ela própria enfatiza: também na América portuguesa o monarca era a instância máxima de ordenação social e a importância de um indivíduo à escala local era mais acentuada quando se baseava na influência da monarquia na definição e na estruturação dos grupos sociais. Um proprietário de lavras afortunado não pode ser equiparado a um camarista ou a um capitão das ordenanças, já que estes exerciam funções nobilitantes. Por outro lado, estes não possuiam o mesmo prestígio social dos súditos que foram titulados como nobres ao conquistarem uma mercê régia, como um hábito da Ordem de Cristo, por terem se destacado em benefício dos interesses da monarquia. É verdade que todos podiam ser reconhecidos como nobres, ou principais, mas só os últimos foram nobilitados aos olhos do rei e pertenciam ao estamento nobiliárquico porque percorreram as vias tradicionais de enobrecimento e beneficiaram-se da economia moral do dom.

Ser agraciado pelo rei com uma mercê nobilitante significava obter uma distinção mais elevada porque o reconhecimento régio da superioridade social implicava que as qualidades que os tornavam partícipes da nobreza local fossem postas à prova pelo centro político. Em outras palavras significava obter a validade jurídica da autoridade social conquistada localmente, acrescida porque as mercês sustentavam as opiniões, refrescavam a memória, canalizavam "o favor do rei com o assentimento das gentes, uma vez que 'pela maior parte, o povo viv(ia) da opinião do Rei e dos grandes que o governa(va)m'"'31. 
Diferentemente do que afirma Silva, para quem a nobilitação dependia estritamente da sanção dos tribunais régios. SILVA, Maria Beatriz Nizza. Ser Nobre na Colônia..., Op. Cit.

33

VIDIGAL, Luis. No microcosmo social português..., Op. Cit, p.120. BICALHO, Maria Fernanda. As câmaras ultramarinas..., Op.Cit, p.202.

34

STUMPF, Roberta. Cavaleiros do ouro..., Op.Cit, Capítulo 4.

35

CUNHA, Mafalda Soares da \& MONTEIRO, Nuno Gonçalo. Governadores e capitães-mores do império atlântico português nos séculos XVII e XVIII. In: MONTEIRO, Nuno Gonçalo; CARDIM, Pedro; CUNHA, Mafalda S. da (org). Optima Pars... Op.Cit., p.197.
Observa-se assim que é justamente porque distintos padrões societários (local e reinol) coexistiam que podemos afirmar que a nobreza colonial era heterogênea, hierarquizada em distintos patamares cujo acesso dependia, fundamentalmente, das estratégias ascensionais percorridas. Se a notoriedade atribuída localmente era uma forma de nobilitação ${ }^{32}$, aquela advinda da anuência régia explícita ainda era mais importante, razão pela qual no interior das nobrezas coloniais um grupo se sobressaía por ser portador dos mesmos atributos que definiam as nobrezas civis na monarquia portuguesa em todos os seus quadrantes.

Neste sentido, o engrandecimento que os monarcas conferiam não foi desprezado, em particular por aqueles que queriam ser honrados pelos reis por thes ter servido. Não havia porque desconsiderar essa possibilidade se a própria monarquia Ihes concedia essa oportunidade de elevar seu status social. Se tais serviços normalmente não Ihes autorizavam a requerer os privilégios de maior distinção, exclusivos à alta aristocracia, por outro lado permitiam que conquistassem postos e títulos que, embora mais modestos, os diferenciavam em relação àqueles principais da região que não conquistaram uma mercê régia que legitimava o pertencimento, também, à nobreza oficial. Genericamente denominados de "nobres da terra", a verdade é que nem todos os súditos contemplados nesta categoria obtiveram o consentimento régio da reputação social conferida a priori pelos conterrâneos, razão pela qual não pertenciam explícita e legalmente ao estamento superior. Viviam todos como nobres, ocupavam postos de prestígio, entretanto muitos ainda eram, do ponto de vista jurídico, plebeus ${ }^{33}$ ou, na melhor das hipóteses, portadores de uma nobreza de abrangência apenas local.

Para se compreender as clivagens sociais na América é preciso considerar as mudanças e permanências que foram se consolidando em relação ao modelo hierárquico vigente no velho continente. É esta a originalidade da sociedade americana, a qual, em absoluto, aponta para uma ruptura.

Nobres de distintas importâncias: a trajetória dos cavaleiros do ouro nas Minas $^{34}$

Dito isto, resta recorrer à documentação para sustentarmos nossas afirmativas. Os exemplos de súditos portadores de prestígio na América que no século XVIII procuram engrandecer e oficializar sua reputação solicitando mercês nobilitantes às instituições metropolitanas são recorrentes. Basta dar uma olhada nos índices referentes aos manuscritos do Arquivo Histórico Ultramarino para notarmos como eram os próprios vassalos assistentes nesta conquista que reconheciam a importância dessa estratégia às suas trajetórias de ascensão. Independentemente do local de residência, conheciam as normas expressas no Registro Geral das Mercês e nelas se pautavam para mostrarem que eram dignos de receberem uma recompensa pelos serviços em prol da monarquia.

Referimos-nos essencialmente a solicitações de mercês que garantiam o acesso à nobreza rasa, já que "em toda a América portuguesa do século XVIII o acesso às distinções nobiliárquicas superiores tornou-se muito raro" ${ }^{135}$. No que diz respeito à capitania de Minas Gerais, a consulta aos indices do Arquivo Histórico Ultramarino revela que os habitantes muitas vezes se socorreram das vias oficiais para elevar seu cabedal social, principalmente solicitando mercês de provimento, ou de confirmação, de postos administrativos e patentes militares, muitos dos quais poderiam Ihes conferir a nobilitação tão desejada. Menos freqüentes foram os pedidos 
36

SILVA, Maria Beatriz Nizza da. Ser Nobre na Colônia..., Op. Cit., p.15-16. A concessão de tais honras, no Brasil, só se tornou freqüente no período imperial. CUNHA, Rui Vieira da. Figuras e fatos da nobreza brasileira. Rio de Janeiro: Ministério da Justiça, Arquivo Nacional, 1975. ZÚQUETE, Afonso Eduardo Martins (dir). Nobreza de Portugal e do Brasil. Lisboa: Zairol, 1989.

37

Arquivo Histórico Ultramarino/ Minas Gerais (AHU) MG), Cx.16, Doc.125; AHU/ MG, Cx.22, Doc. 64.

38

AHU/MG, Cx.16, Doc.96; AHU/MG, Cx.25, Doc.25; AHU/MG, Cx.66, Doc.56; AHU/MG, Cx.147, Doc.33; AHU/MG, Cx.139, Doc.17.

39

OLIVEIRA, Luiz da Silva Pereira. Privilégios da Nobreza e Fidalguia de Portugal. Apud. MONTEIRO, Nuno Gonçalo. Notas sobre a nobreza....Op.cit, IDEM. Elites locais e mobilidade social em Portugal..., Op. Cit., p.343. Sobre as Ordens militares em Portugal ver o excelente estudo: OLIVAL, Fernanda. As ordens militares e o Estado moderno. Honra, mercê e venalidade (1641-1789). Lisboa: Coleção Thesis. 2001.

40

Regimento para a nova forma de cobrança do direito senhorial dos quintos dos moradores das Minas Gerais, abolida a da Capitação que antes se praticava. Apud. SOUSA, José Roberto Monteiro de Campos Coelho de. Systema ou Collecção dos Regimentos Reais. Lisboa: Oficina Francisco Borges de Sousa, 1783. p.322. Disponivel em www.iuslusitania.fcsh.unl.pt. Acesso em 21/10/2008.

41

"a mesma preferência (aos cargos e mercês), e as mesmas certidões darão também os respectivos governadores a todas as pessoas, que dentro no espaço de um ano meterem em alguma Casa de Fundição oito arrobas de ouro, ou dali para cima, sem que examinem, se o dito ouro era próprio dos que trouxeram a fundir, ou alheio; porque todos os que no seu nome fizerem fundir dentro de um só ano as referidas oito arrobas, gozarão dos sobreditos benefícios em gratificação de seu louvável trabalho e da sua benemérita indústria". (grifos nossos). Regimento para a nova forma de cobrança do direito senhorial dos quintos..., $0 p$. Cit., Capítulo 9 parágrafo 4. de mercês honoríficas. Em todo o Setecentos não encontramos nenhum referente aos títulos nobiliárquicos, o que corrobora a idéia de Silva de que poucos titulares estavam ligados à história colonial. ${ }^{36}$ Quanto às comendas das Ordens militares, entre os habitantes das Minas, apenas Garcia Rodrigues Paes e José Rebelo Perdigão, na década de 1730, julgaram-se dignos de tão importante remuneração, embora nenhum tenha sido agraciado. ${ }^{37}$ Quanto ao foro de fidalguia, fora requerido em cinco petições ${ }^{38}$ ao longo de toda esta centúria. Também aqui nenhum dos suplicantes foi contemplado, nem mesmo Bernardo da Fonseca Lobo, o "descobridor dos diamantes", já que os solicitantes só tinham serviços a oferecer e não pertenciam a uma linhagem de irrefutável prestígio, como era normalmente exigido nestes casos, para que semelhante mercê fosse concedida. Sendo assim, estas distinções "mais apeteciveis" (títulos, comendas e foro de fidalguia) foram requeridas com pouquíssima freqüência, o que, a nosso ver, deviase ao fato dos habitantes terem por certo que eram inacessiveis às suas condições. Sabiam os homens o que pedir e, normalmente, não despendiam tempo e dinheiro na conquista de mercês que, embora fossem prestigiadas, acreditavam não estarem ao seu alcance. No entanto, se para conquistarem a nobilitação oficial normalmente procuravam obter oficios e patentes superiores, honras de menor importância simbólica configuravam-se também no horizonte de expectativas dos vassalos residentes nas Minas, como os hábitos das Ordens militares, os quais, juntamente com os cargos de distinção, eram aqueles que, segundo Oliveira, "de ordinário costumam andar em gente nobre" ${ }^{\prime 39}$.

Neste sentido, o sistema de doação de mercês encabeçado pelo rei estendeu-se às Minas Gerais, sendo também ali responsável pela consolidação de uma nobreza colonial titulada pela monarquia. Ainda assim, se nessa capitania vemos que alguns súditos portavam as mesmas qualidades definidoras da nobreza em todo o território português, é preciso lembrar que as especificidades locais sempre estiveram presentes já que, no que se refere também a este sistema, a natureza dos serviços remuneráveis apresentava algumas diferenças em cada uma das partes da América.

A capitania das Minas Gerais, por não ter sido palco de guerras de maior vulto, nas quais se lutavam contra as potências estrangeiras, não propiciou a obtenção de mercês de maior poder simbólico, dadas, como se sabe, aos que agiam com fidelidade em contexto de maior periculosidade bélica. Entretanto, a imagem de uma localidade rica e insubmissa, que predominou no discurso oficial, foi apropriada por alguns habitantes para exaltar suas qualidades perante os tribunais régios, e assim ganhar maior projeção social naquelas terras. Servir em uma capitania próspera onde a indole dos residentes era definida pejorativamente tinha suas vantagens. A desordem de muitos favorecia os ímpetos nobilitantes de poucos, que puderam se destacar no combate ao extravio, às revoltas anti-fiscais ou ainda na descoberta de novas lavras auriferas. A partir de 1750, com a Lei de Estabelecimento das Casas de Fundição ${ }^{40}$, a monarquia portuguesa possibilitou ainda que a fidelidade expressa em arrobas de ouro rendesse aos súditos ali residentes um hábito das Ordens militares, o que não era pouco em uma região onde a fidalguia e a nobreza de sangue rareavam. No capitulo 9, parágrafo 4 deste Regimento que modificou a forma de cobrança fiscal, está expressa a promessa de recompensar os súditos que fizessem entrar nas Casas de Fundição mais de oito arrobas de ouro anualmente. ${ }^{41}$ Ali não encontramos nenhuma referência à qualidade dos que poderiam ser 
42

A ausência da qualidade dos súditos não se constituía em uma flexibilização inovadora já que também o primeiro Regimento das Mercês de 1671 não discriminava a condição social dos súditos que poderiam solicitar mercês. OLIVAL, Fernanda. As ordens militares e o Estado moderno..., Op.Cit, p.122.

43

Dos 89 suplicantes, 42 conquistaram a mercê de um hábito das Ordens militares. Destes, pudemos consultar o processo de habilitação de vinte e nove porque oito foram dispensados das provanças, enquanto que cinco tiveram seus processos extraviados, embora sabemos que conseguiram se tornar cavaleiros.

44

AHU/MG, Cx.95, Doc.30, f.1.

45

0 fato de pouco mais da metade dos que buscaram esta alternativa de enobrecimento não ter obtido sucesso perante o Conselho provavelmente ocorreu devido à dificuldade de apresentar os papéis necessários à comprovação da idoneidade do serviço. Não encontramos nenhum parecer emitido por esse tribunal régio que fosse desfavorável à remuneração porque os solicitantes foram considerados indignos dela por seus atributos pessoais ou ancestrais.

46

Sobre os trâmites burocráticos à habilitação de cavaleiros das Ordens Militares ver OLIVAL, Fernanda Olival. Mercês, serviços e circuitos documentais no império português. In: SANTOS, Maria Emília Madeira; LOBATO, Manuel (coord). 0 Domínio da Distância. Comunicação e Cartografia. Lisboa: História e Cartografia, Departamento de Ciências Humanas, Instituto de Investigação Científica Tropical, 2006. p.65-70. beneficiados nem à natureza da mercê com a qual podiam ser agraciados. ${ }^{42}$ 0 fato de todos os que desempenharam semelhante serviço, num total de oitenta e nove indivíduos entre 1750 e 1808, solicitarem a insígnia de cavaleiro de uma Ordem militar, quando podiam solicitar mercês diversas, nos mostra não apenas a importância desta honraria, mas sobretudo o que dissemos anteriormente: os súditos tinham noção que suas qualidades não eram compativeis com distinções honorificas superiores.

Tal afirmativa, no entanto, só ganha sustentação se acompanharmos o desenrolar destes processos de nobilitação. É verdade que a promessa de remuneração, expressa na Lei de 1750 , contemplava aqueles que entregassem a avultada quantia de 8 arrobas, o que correspondia a quase 10\% do que toda a capitania devia contribuir anualmente. À primeira vista, somos levados a crer que a Coroa estaria contribuindo legalmente para que o mérito da riqueza se tornasse o principal fator de enobrecimento. Mas, embora $2 / 3$ dos 42 súditos que conquistaram um hábito militar por semelhante serviço fossem reconhecidos como homens de posses e/ou de cabedal, não era preciso ser abastado para conseguir uma mercê régia pela contribuição desta quantia de ouro. ${ }^{43} 0$ próprio Regimento autorizava o registro das entradas em nome de terceiros, supostamente vassalos que possuiam prestígio suficiente para convencer outros habitantes a contribuir com a Fazenda Real de forma a beneficiá-los. Ao Conselho Ultramarino não era preciso provar que 0 ouro lhes pertencia, apenas juntar às suas petições documentos que atestassem serem eles os favorecidos com o serviço supostamente executado por dezenas de vassalos. Assim, Agostinho Soares Francisco, em sua petição, esclarecia que na década de 60 contribuiu com mais de oito arrobas de ouro

\footnotetext{
seu próprio, e de vários mineiros, e comerciantes de cujas mãos fez sair e pelas suas encaminhado e dirigido diretamente à dita Fundição (de Vila Rica) no que atualmente continua, e trabalha vigilantemente afim de não passar em pó, nem vagar disperso no giro do comércio com o risco quase certo de se extraviar para fora da Capitania e Conquista. ${ }^{44}$
}

À Coroa não interessava saber a origem de tal riqueza, mas sim que essa saísse de circulação e não caísse nas mãos dos contrabandistas. Neste sentido, os homens que foram contemplados com a Lei de 1750 não 0 foram porque eram ricos, mas sim porque propiciaram que o ouro entrasse nos cofres reais, serviço que a própria monarquia, a partir dessa data, entendia ser altamente remunerável. Se era o serviço em si o objeto de recompensa perante os oficiais do Conselho Ultramarino, é possivel entender por que nas solicitações de mercês os suplicantes não se deram ao trabalho de enumerar suas qualidades valorativas, caso as possuissem..$^{45} \mathrm{Afinal}$, elas só seriam objeto de julgamento depois que os conselheiros se pronunciassem favoravelmente, quando então eram iniciadas as provanças pela Mesa de Consciência e Ordens. Somente nessa segunda fase é que era preciso comprovar ser portador de qualidades enaltecedoras, há séculos exigidas à obtenção do título de cavaleiros das Ordens militares. ${ }^{46}$ Ao longo destas inquirições vemos que o cabedal econômico constituía-se num dos atributos a conferir notoriedade local, embora em nenhum dos processos a aptidão dos candidatos para ingressar na Ordem tenha sido atestada em função de seus cabedais. As virtudes tradicionais é que estavam em julgamento, vale dizer, aquelas que faziam dos súditos homens virtuosos, fiéis e valorosos aos olhos do poder central. 
De qualquer forma, não deixa de ser significativo que entre os 42 suplicantes que conquistaram a mercê do hábito, pouco mais da metade não foi considerada inicialmente apta para receber o título de cavaleiro militar, por ter algum impedimento em sua pessoa ou em seus ancestrais. Tal número poderia ser ainda mais elevado se $19 \%$ não tivessem conquistado a dispensa de suas provanças, o que passou a ser comum no final do século XVIII, para infelicidade dos pesquisadores que ficam impossibilitados de saber se estes portavam ou não qualidades "desclassificatórias". Apenas $21 \%$ dos habilitandos eram tidos e havidos como pessoas que portavam as características condizentes com as exigências dos Estatutos das Ordens e, se todos acabaram por se tornar cavaleiros, não se deve, voltamos a repetir, ao fato de serem ricos.

Tabela 1- Provanças: parecer final

\begin{tabular}{|c|c|c|}
\hline Parecer final & $\begin{array}{c}N^{\circ} \text { de } \\
\text { habilitados }\end{array}$ & $\%$ \\
\hline Habilitado sem impedimento & 9 & $21.42 \%$ \\
\hline $\begin{array}{c}\text { Habilitado com dispensa das provanças } \\
\text { e habilitações }\end{array}$ & 8 & $19,04 \%$ \\
\hline Total & 17 & $40,4 \%$ \\
\hline Habilitados com impedimentos & 12 & $26,19 \%$ \\
\hline $\begin{array}{c}\text { Habilitado com dispensa gratuita do impedimento } \\
\text { Habilitado com dispensa do impedimento paga em } \\
\text { donativo em dinheiro }\end{array}$ & 9 & $21,42 \%$ \\
\hline $\begin{array}{c}\text { Habilitado com dispensa do impedimento paga em } \\
\text { donativo em dinheiro e serviços futuros }\end{array}$ & 1 & $2,38 \%$ \\
\hline Total & 22 & $52,38 \%$ \\
\hline Sem parecer final & 3 & $7,14 \%$ \\
\hline TOTAL GERAL & 42 & $100 \%$ \\
\hline
\end{tabular}

Fonte: ANTT/ Habilitações de Cavaleiros das Ordens Militares

Dos 42 cavaleiros do ouro, 35 eram naturais do Reino e 3 da capitania de Minas Gerais (não foi possivel saber a naturalidade de quatro). Quanto aos reinóis, 25 eram seguramente do Minho, região localizada ao Norte de Portugal.

48

TORRES, José Viegas. Da Repressão Religiosa para a Promoção social. A Inquisição como instância legitimadora da promoção social da burguesia mercantil. Revista Crítica de Ciências Sociais, Lisboa, n.40, p.113, outubro de 1994. CALAINHO, Daniela Buono. Agentes da fé. Familiares da Inquisição Portuguesa no Brasil Colonial. Bauru/São Paulo: Edusc, 2006. RODRIGUES, Aldair Carlos. Sociedade e Inquisição em Minas colonial: os familiares do Santo Ofício (1711-1808). (Mestrado em História Social). Faculdade de Filosofia, Letras e Ciências Humanas da Universidade de São Paulo, São Paulo, 2007.
Quanto aos 22 solicitantes que sabemos serem portadores de impedimentos, apenas 4 não traziam em si a mácula da mecânica, e se foram considerados indignos do hábito que requeriam era porque apresentavam alguma deficiência física (como a cegueira) ou por possuírem mais de 50 anos (o que não era considerado grave principalmente porque as Ordens militares há muito deixaram de exigir que seus cavaleiros pegassem em armas). Vale a pena observar que a impureza de sangue não aparece como impedimento em nenhum dos casos analisados, questão que nos sugere distintas interpretações. Se lembrarmos que a maioria se habilitou antes da lei de 25 de maio de 1773, que marcou definitivamente o fim dos estatutos de limpeza de sangue, o fato das provanças não mencionarem este defeito pode indicar a ascendência cristã-velha dos candidatos ${ }^{47}$ ou, por outro, que tal mácula não se constituía um obstáculo à obtenção do hábito, ao contrário do que ocorria para aqueles que desejavam pertencer aos quadros burocráticos do Tribunal do Santo Ofício. ${ }^{48}$ 


\begin{tabular}{|c|c|c|}
\hline Natureza do impedimento & Nosuplicantes & $\%$ \\
\hline Mecânica pessoal & 4 & $18,18 \%$ \\
\hline Mecânica na familia & 7 & $31,81 \%$ \\
\hline Mecânica pessoal e na família & 3 & $13,63 \%$ \\
\hline Mecânica pessoal e maior de 50 anos & 1 & $4,54 \%$ \\
\hline $\begin{array}{c}\text { Mecânica pessoal, na familia e maior } \\
\text { de 50 anos }\end{array}$ & 3 & $13,63 \%$ \\
\hline Maior de 50 anos & 3 & $13,63 \%$ \\
\hline "Aleijão" & 1 & $4,54 \%$ \\
\hline TOTAL & 22 & $100 \%$ \\
\hline
\end{tabular}

Fonte: ANTT/ Habilitações de Cavaleiros das Ordens Militares

De qualquer forma, o principal impedimento referido nas provanças dizia respeito à natureza da atividade a qual os candidatos ou seus familiares se dedicavam. Quando a impureza de oficio provinha de um ancestral, de um dos pais ou de um dos quatro avós, normalmente estes haviam desempenhado alguma atividade vil para sobreviver, como ser assalariado, embora nenhum dos habilitandos fosse reconhecido como descendente de famílias pobres. Na verdade, quase todos receberam de seus pais uma educação elementar, e se migraram para a América e subiram as serras que separavam as Minas do litoral é porque acreditavam que ali poderiam encontrar oportunidades muito mais promissoras para ascender socialmente do que aquelas de que disporiam caso se enraizassem em suas pátrias de nascimento.

Se grande parte dos candidatos carregava o estigma da mecânica que, como vimos, obstacularizava o acesso oficial à nobreza, resta saber por que a Coroa acabou por consentir a doação do hábito mesmo àqueles cujas histórias de vida não Ihes era especialmente favoráveis, segundo os critérios estipulados pela Mesa de Consciência e Ordens. É claro que podemos pensar que a monarquia tinha especial interesse na habilitação destes vassalos já que seus impedimentos poderiam ser dispensados mediante 0 pagamento de um donativo. No entanto, ao menos nos casos aqui analisados, menos da metade dos "impedidos" contribuiu com um donativo pecuniário para se ver livre de seus defeitos. Os demais conquistaram a dispensa gratuita e uma das razões enunciadas para justificar tal graça era o fato de terem efetuado um serviço próprio, assim entendido porque a entrega das arrobas de ouro foi feita em seus nomes e não no de outros que poderiam ter-lhes renunciado o serviço ou a mercê já consentidos. Vemos, por exemplo, no processo de habilitação de Caetano José Rodrigues que este solicitou a dispensa do defeito de mecânica - seus avós maternos eram jornaleiros - alegando que recebeu a mercê do Conselho Ultramarino

Arquivo Nacional da Torre do Tombo/ Habilitações da Ordem de Cristo (ANTT/HOC), Letra C, Maço 06, Número 11, f.1 e f.5. "por seus próprios e exuberantes serviços" ${ }^{49}$, vale dizer, por ter feito entrar vinte arrobas de ouro na Casa de Fundição de Vila Rica em 1754-55, quantidade bem acima da média de 8 a 9 arrobas. Sua justificativa foi acatada pelo monarca e pelos deputados da Mesa que o habilitaram em 1766, com dispensa gratuita. As virtudes meritocráticas eram valorizadas neste tipo 
51

AHU/MG, Cx.92, Doc.03, f.1. de processo sendo recorrente os súditos, cujas "ações no Real Serviço têm sido maiores do que o seu nascimento" ${ }^{50}$, serem premiados, conforme palavras dos deputados expressas em uma das provanças consultadas.

Não podemos deixar de considerar também que a habilitação destes vassalos constituia-se numa estratégia para incentivar os habitantes das Minas a depositarem o ouro nos cofres reais. Embora a contribuição do quinto fosse obrigatória, em uma capitania onde o contrabando ganhou, aos olhos dos oficiais régios, uma intensidade alarmante, o depósito das arrobas de ouro era um serviço reconhecido como louvável. Afinal, a imposição do Regimento de 1750, como alguns suplicantes procuravam lembrar em suas petições, fora a maneira encontrada pela Coroa de "esperançar de prêmio os vassalos das Minas que Ihe fizessem o dito serviço a fim de facilitar as entradas do ouro nas ditas Casas e evitar o seu extravio" ${ }^{51}$. Parece compreensivel que para combater a desordem ali reinante, o melhor remédio era premiar aqueles que seguiam o partido da fidelidade, ainda que esta fosse esperada de todos. 0 que foi feito já que os que comprovaram 0 serviço tornaram-se cavaleiros, não obstante alguns terem que recorrer à Coroa para verem suas qualidades "desabonatórias" aliviadas.

Mas a fidelidade expressa com a entrega das arrobas não aparece na documentação como a principal justificativa para embasar a decisão da Mesa de "perdoar" os impedimentos dos candidatos. Na verdade, a decisão régia de conceder os hábitos não se pautava unicamente na natureza do serviço desempenhado já que também as exigências tradicionais ao ingresso às Ordens militares eram requeridas dos habilitandos, o que parece estar conforme a idéia de que a maior distribuição de mercês honorificas na segunda metade do século XVIII não fragilizou sensivelmente a reputação associada à nobreza.

É significativo que todos os habilitandos em suas trajetórias individuais demonstraram respeito aos valores hierárquicos da cultura política do Antigo Regime, trilhando seus percursos nas Minas de forma a conquistar uma reputação que poderia Ihes render o reconhecimento régio de suas virtudes. Primeiramente, todos eram descritos pelas testemunhas como homens reputados que viviam "à lei da nobreza", não obstante o fato de alguns serem identificados como portadores da estigma da mecânica. Somados ao modo de vida que levavam, os serviços prestados à monarquia e ao bem comum contribuiram para que deles se formassem uma imagem enaltecedora, digna de servir de exemplo aos demais súditos portugueses.

Veja-se assim que apesar de muitos dos suplicantes serem homens de cabedal, não era a riqueza a fonte primordial ao reconhecimento da notoriedade que possuiam localmente. Os serviços prestados à Coroa ainda eram o principal indicador da importância dos indivíduos, o que pode explicar porque cerca de $95 \%$ daqueles que se tornaram cavaleiros graças à entrega do ouro pertenceram, em algum momento de suas trajetórias, à estrutura burocrática e militar da capitania das Minas Gerais. Em sintese, os vassalos ali residentes depositavam todas as suas esperanças ascensionais na cultura de serviços, o que significa que também naquelas paragens o monarca era visto como uma instância decisiva e com pretensão ao monopólio da configuração das hierarquias sociais. Tal afirmativa não exclui, porém, a importância que os critérios locais de hierarquização possuiam. 0 que desejamos mostrar é que nas Minas, a infidelidade não era a regra e a autonomia, frequentemente associada aos mineiros, não eliminava necessariamente os desejos de ascensão de alguns súditos que buscaram as 
vias oficiais para serem reconhecidos pelo monarca e pela população local, como homens prestigiados.

Tabela 3 - A trajetória dos suplicantes nas Minas: o provimento de cargos civis e militares

\begin{tabular}{|c|c|c|}
\hline Cargos e patentes militares & n. de suplicantes & $\%$ \\
\hline $\begin{array}{c}\text { Suplicantes com } \\
\text { cargos civis }\end{array}$ & 10 & $23,8 \%$ \\
\hline Sem patente militar & 14 & $33,33 \%$ \\
\hline Com patente militar (conquistada depois) & 10 & $23,8 \%$ \\
\hline Com patente militar (conquistada antes) & 34 & $80,93 \%$ \\
\hline Total & & \\
\hline $\begin{array}{c}\text { Suplicantes } \\
\text { Com cargos militares }\end{array}$ & 6 & $14,28 \%$ \\
\hline Sem cargos civis & 40 & $95,21 \%$ \\
\hline $\begin{array}{c}\text { Total geral } \\
\text { suplicantes com cargos }\end{array}$ & 2 & $4,76 \%$ \\
\hline & 42 & $100 \%$ \\
\hline Suplicantes sem cargos & & \\
\hline TOTAL GERAL & & \\
\hline
\end{tabular}

Fonte: AHU/ Manuscritos avulsos relativos a Minas Gerais; ANTT/ Habilitações de Cavaleiros das Ordens Militares, ANTT/ Habilitações do Santo Ofício

Tampouco pretendemos desmerecer a relevância da riqueza nos processos ascensionais destes vassalos aqui analisados. Já foi dito que pouco menos de 3/4 são descritos como homens de posses e/ou cabedal principalmente porque puderam enriquecer mediante o desempenho da atividade comercial. Essa qualidade, sem dúvida, contribuiu para que conquistassem postos de prestígio na administração local ou mesmo que fossem nomeados para patentes militares mais elevadas, mesmo quando não possuiam nenhuma experiência nas armas. Todavia, para estes que não nasceram nobres, ainda que o cabedal econômico tivesse contribuído para sua trajetória ascendente, o servir à Coroa continuava a ser a principal via de nobilitação, 0 que pode explicar a distância temporal entre a data da entrega do ouro e da solicitação de um título de cavaleiro. Na verdade, os solicitantes mostravam ter ciência de que a contribuição pecuniária às Casas de Fundição, se era suficiente para legitimar seus desejos nobilitantes, não o era para que fossem reconhecidos pela sociedade e pelos deputados da Mesa como súditos dignos de obterem um hábito de uma Ordem militar. Ela garantia a concessão da mercê pelo Conselho Ultramarino, se conseguissem comprovar o serviço, mas não era capaz de assegurar o sucesso nas provanças. Sendo assim, após o depósito das arrobas de ouro o mais comum foi que esperassem anos para solicitar uma recompensa, objetivando acumular serviços de outras naturezas que engrandecessem seus nomes e confirmassem seu merecimento.

Vemos o exemplo de Silvestre Fernandes dos Reis, que fizera entrar em 1754-55 mais de doze arrobas na Casa de Fundição de Vila Rica e que 
AHU/MG, Cx.94, Doc.05. Sobre Silvestre dos Reis ver SILVA, Maria Beatriz Nizza da. A Coroa e a remuneração dos vassalos. In: RESENDE, Maria Efigênia Lage de; VILLALTA, Luiz Carlos (org). História das Minas Gerais. As Minas Setecentistas. Belo Horizonte: Editora Autêntica, 2007. p.191220.

Arquivo Nacional da Torre do Tombo/ Habilitação do Santo Ofício (ANTT/HSO), Maço 02, diligência 24.

54

No Memorial histórico-político da Câmara Municipal de Ouro Preto, Silvestre dos Reis aparece como juiz mais moço em 1767, e juiz mais velho em 1772. Memorial histórico-político da Câmara Municipal de Ouro Preto, Ouro Preto limitada, 2004.

55

ANTT/HOC, Letra S, Maço 5, Número 8, f.8.

56

A exigência de se ter menos de cinqüenta anos cai em desuso "com o desaparecimento das funções militares das Ordens". MELLO, Evaldo Cabral de. Rubro Veio. 0 imaginário da restauração pernambucana. Rio de Janeiro: Topbooks, 1997. p.235.

57

A mercê lhe fora concedida em 1777. Arquivo Nacional da Torre do Tombo/Registro Geral das Mercês (ANTT/RGM), D.Maria I, liv.2, f.248v. esperou cerca de quinze anos para requerer a mercê do hábito de Cristo. ${ }^{52}$ Tendo chegado às Minas ainda menino, fora acolhido por um tio que ali residia e que sempre o tratou "com muita distinção". Com cerca de trinta e cinco anos conquistou o título de familiar do Santo Oficio e, já nas inquirições, concluidas em 1744, era tido pelas testemunhas como um homem reputado que vivia "limpa e abastadamente" não só porque tinha um volumoso cabedal de sete mil cruzados, mas porque se dedicava ao comércio de escravos, empregando os seus nas lavras que tinha na região. Sua importância era acrescida pelo fato de seus pais e avós, na freguesia do termo de Barcelos, Arcebispado de Braga, serem "lavradores que viveram limpamente de seus bens". Até mesmo a fama que corria nas Minas de que tinha um filho da escrava de seu tio, só porque "se assemelhavam nas feições!", foi entendida como sem fundamento pelos freis inquiridores frente ao prestígio que já adquirira na região, sempre passivel de ser caluniado por invejosos. ${ }^{53}$

Sendo assim, quando entregara o ouro não portava nenhuma qualidade desclassificatória, mas se esperou alguns anos para solicitar a mercê é porque sabia que no processo de habilitação a cavaleiro o fato de ser comerciante poderia se constituir em obstáculo, o mesmo não acontecendo no processo de familiatura. No intuito de criar todas as condições favoráveis à obtenção do hábito, só o requereu depois de ser provido no cargo de juiz ordinário de Vila Rica ${ }^{54}$, oficio que merecia toda a deferência dos habitantes da região. E de fato, em suas provanças, as testemunhas enfatizam sua reputação, lembrando sua condição de juiz, assim como a de um homem que vivia à lei da nobreza compatível com seu prestígio e seu cabedal. 0 padre Manoel Marinho da Silva, vigário colado na freguesia de Nossa Senhora da Conceição em Antonio Pereira, Bispado de Mariana, confirmava que Reis se tratava sempre "com muito luzimento em suas cavalgaduras e criado de o acompanhar e tendo sido juiz ordinário por várias vezes isto em Vila Rica, (....) (e que era) bem reputado entre todos os homens bons" ${ }^{\prime 5}$. Sua estratégia, porém, causou-Ihe um dano: os anos se passaram e, quando suas provanças se realizaram, Reis já tinha mais de cinqüenta anos, o que o tornava inapto para adquirir o hábito. No entanto, a exigência da idade remontava ao período no qual as Ordens caracterizavam-se essencialmente por suas funções militares. ${ }^{56}$ No século XVIII, um homem outrora considerado senil para tornar-se cavaleiro poderia habilitar-se sem problemas se fosse prestigiado; já não era esperado que com tal título pegasse em armas. E foi exatamente isso que ocorreu, pois Reis habilitou-se em 1779 depois de ter trilhado uma trajetória de grande sucesso nas Minas ao longo de cinqüenta e nove anos. ${ }^{57}$

Grande parte dos suplicantes aproveitou todas as oportunidades que Ihes eram oferecidas para ascender socialmente, inclusive aquela concedida pela entrega do ouro. 0 fato de terem solicitado um hábito da Ordem militar por esse serviço, e não por aqueles que puderam desempenhar servindo na administração ou no exército, pode ser explicado tendo em vista as trajetórias dos requerentes. Alguns, quando enviaram a petição ao Conselho Ultramarino, não haviam servido o mínimo de doze anos exigidos pelo Regimento das Mercês, pelo que só poderiam ser remunerados naquele momento pelo zelo em contribuir para com o Erário Régio. Outros, que já atuavam há mais tempo nas Minas, supostamente fizeram uso da Lei de 1750 porque o mérito atribuído ao serviço da entrega das arrobas Ihes garantia legalmente a obtenção do hábito, o mesmo não ocorrendo com eventuais serviços que desempenharam em outras esferas. 
58

Sabemos o estado civil de 32 suplicantes no momento em que foram habilitados para entrar na Ordem. Destes, 25 eram solteiros.

59

OLIVAL, Fernanda. As Ordens militares..., Op.Cit. p.376.
Porque o hábito era concedido pela contribuição do ouro, mas apenas aos bons servidores da monarquia, vemos que estes súditos solicitaram tal mercê normalmente quando já eram portadores de reputação nas Minas. Isso explica por que a maioria se tornou cavaleiro na faixa etária de 40-50 anos, sendo muitos ainda solteiros ${ }^{58}$, uma vez que também o matrimônio só devia ser contraído depois de conquistarem uma situação minimamente desejável que lhes permitia unirem-se a jovens de famílias igualmente prestigiadas, ou mesmo arcarem com os custos de manter uma casa. Considerando os dados apresentados por Fernanda Olival sobre a idade média dos habilitados no século XVIII (entre os 30-40 anos), nota-se que nas Minas era preciso percorrer um trajeto mais longo para conquistar uma insígnia de um hábito militar. ${ }^{59}$

Pelo que podemos concluir que se estes vassalos foram agraciados com uma mercê por um feito que não durara mais de um ano, o título de cavaleiro só thes fora concedido porque conseguiram comprovar que ao longo de suas vidas adquiriram notoriedade não apenas por serem ricos, mas porque se comportavam como nobres e, sobretudo, porque atuavam com fidelidade à Coroa no desempenho de cargos reputados. Se o monarca dispensou alguns "defeitos", não era somente porque devia se mostrar misericordioso ou porque necessitava de recursos financeiros. Dispensou porque a pouca qualidade dos mesmos não era sórdida, e porque estes deram demonstrações de fidelidade e respeito à cultura política tradicional. Aos olhos dos homens comuns o Rei agia com justiça, pois reconhecia que as virtudes destes bons vassalos e exemplares servidores compensavam suas eventuais "faltas". A flexibilização das exigências contidas nos Estatutos das Ordens militares, além de não ameaçar a ordem social, assegurava o poder do monarca na delimitação das clivagens entre seus súditos.

\section{Uma breve conclusão}

Dos casos aqui relatados, diversos pontos podem ser inferidos, muitos já mencionados anteriormente, como a importância atribuída à riqueza na reputação dos vassalos coloniais. Se é sabido que a pobreza ao longo do Antigo Regime não era compatível com a nobreza, aquela nunca se configurou enquanto virtude predominante na avaliação da dignidade dos súditos quando estes recorreram aos tribunais régios com vistas a serem nobilitados. Se nos âmbitos locais o cabedal facilitou os percursos ascensionais, como o acesso aos cargos e patentes militares, também aos olhos dos habitantes da América a reputação dos indivíduos era fortalecida quando estes se "sacrificavam" em benefício da monarquia e do bem comum, principalmente quando por tais serviços fossem reconhecidos como homens valorosos pelo centro político. Pelo que, pode-se concluir, a riqueza, por mais importante que fosse para a conquista da notoriedade, não era o critério principal. Aos que sonhavam mais alto, e compartilhavam a relevância do sistema das mercês, recorrer à cultura de serviço era a melhor estratégia para coroar seus percursos ascendentes.

Como procuramos mostrar, na América, o rei era reconhecido por muitos como aquele que detinha, senão o monopólio, ao menos um papel primordial no estabelecimento das hierarquias sociais. Tese partilhada por muitos autores aqui citados. A nobreza sancionada pela monarquia com um título creditado, como era o de cavaleiro das Ordens militares, conferia uma reputação mais destacada também para os homens que viviam no território americano. Isto porque se sobressaiam não só em relação aos plebeus sem 
60

SOUZA, Laura de Mello e. Os desclassificados do ouro. A pobreza mineira no século XVIII. Rio de Janeiro: Editora Graal, 2004. p.204.

Alguns habitantes da América receberam o hábito em Portugal, embora isto não deve ter sido freqüente, dados os custos da deslocação. OLIVAL, Fernanda. As Ordens militares..., Op.Cit., p.458.

62

Tal como entende Fernanda Olival, a maior especialista em Ordens militares em Portugal, OLIVAL, Fernanda. 0 Brasil na disputa pela politica de "mercês extraordinárias" da coroa (séculos XVI-XVIII). In: VAINFAS, Ronaldo \& MONTEIRO, Rodrigo Bentes (org). Império das mil faces. São Paulo: Alameda, 2009. p.170. Lembremos ainda que entre os indivíduos aqui estudados a maioria foi contemplada neste período. qualquer notoriedade como também àqueles principais que não haviam sido agraciados com uma mercê nobilitante, mas que gozavam de uma nobreza de abrangência apenas local. Se com isso observamos uma pluralidade no interior das nobrezas americanas, cremos que para contemplá-la o melhor seria fazer uso de distintas categorias sociais, como nobreza oficial e nobreza tácita. 0 termo "nobreza da terra" é certamente indispensável para qualificar os grupos dirigentes nas distintas partes na América portuguesa. Mas não chega para dar conta das disparidades existentes entre os diferentes territórios e no interior das elites em cada um deles.

Vale a pena frisar mais uma vez que a importância que atribuímos ao reconhecimento da notoriedade dos súditos pelo centro político, expressa mediante a concessão de uma mercê, em hipótese alguma significa que estamos minimizando a relevância dos parâmetros locais na hierarquização social. Como procuramos deixar claro, os tribunais régios consagravam juridicamente a reputação daqueles que já eram tidos e havidos em suas pátrias de origem ou adoção como homens respeitados por sua nobreza tácita. Para que os representantes régios no Reino agissem com justiça, e nobilitassem os homens dignos de tal status social, precisavam considerar e respeitar também aquilo que já era "público e notório".

Neste sentido, ainda que consideremos que a nobreza colonial era um grupo composto por hierarquias internas, as formas de nobilitação de abrangência local e universal não se excluiam, pelo contrário, se influenciavam mutuamente. Nas provanças aqui analisadas, temos inúmeros exemplos de como para as testemunhas a aquisição de uma mercê honorífica ou de um cargo de nomeação régia engrandecia a reputação dos habilitandos ou de seus ancestrais. Não era só a monarquia que sustentava o pressuposto de que a nobreza jurídica era superior. A economia das mercês teve forte impacto também no Império entre os homens livres, porque com ela não era só a Coroa que conquistava novas fidelidades, também os súditos que desejavam engrandecer seu status social tinham-na em grande conta para engrandecer os atributos de notoriedade consolidados localmente. Era-se cavaleiro de uma Ordem militar portuguesa em toda parte, até em outras monarquias, o que se ostentava exuberantemente na cruz que se levava ao peito e que figura em quase todos os retratos da época.

Para entender esta dinâmica entre parâmetros societários diversos, mas nem por isso conflitantes, é que nos debruçamos sobre o estudo dos habitantes das Minas que solicitaram um hábito de cavaleiro das Ordens militares por uma fidelidade demonstrada em arrobas de ouro. Se ao longo de todo o século XVIII ficaram registradas no Conselho Ultramarino apenas 89 solicitações desta natureza enviadas pelos habitantes de uma capitania cuja população rondava a cifra de 350 mil habitantes em $1786^{60}$, isso não se devia a um suposto desprezo pelos critérios de hierarquização tradicionais, nem tampouco a uma índole rebelde associada aos mineiros. Se considerarmos que no período de 1750-1777 cerca de duzentos e oitenta indivíduos se armaram cavaleiros na América ${ }^{61}$, o que corresponde aproximadamente a $10 \%$ do total, vemos que o número de súditos que nas Minas conquistou esta mercê com o auxílio da lei de 1750 não é desprezivel. ${ }^{62}$ É preciso lembrar ainda que estes foram remunerados pelo desempenho de um serviço extraordinário, pois 8 arrobas era uma quantia de grande monta, principalmente em um período no qual o declínio da atividade aurífera era sentido por todos. 
A ideologia de serviços era exclusivista e não poderia ser diferente. Embora muitos criticassem esse sistema por acreditar que promovia um inchaço do estamento superior, a Coroa não contemplou os desejos nobilitantes de forma excessiva, procurando preservar a identidade da nobreza sancionada pelos tribunais régios. Ainda assim, o sistema de mercês teve uma forte eficácia ideológica, que contribuiu para que os parâmetros estamentais de hierarquização coexistissem na América com aqueles que eram próprios deste território. Resta ao historiador analisar a sociedade americana tendo em vista as distintas formas de adquirir reputação social, reconhecendo que não obstante muitos fossem reconhecidos como nobres por seus conterrâneos, segundo critérios eminentemente locais, quando o monarca confirmava juridicamente sua importância social, sua dignidade era acrescida, aos olhos de muitos. 